\title{
POLITIK BAHASA ASING DAN HEGEMONI PESANTREN DI NUSANTARA
}

\author{
Wahyu Hanafi ${ }^{1}$, Rizki Amalia Sholihah ${ }^{2}$ \\ ${ }^{1}$ Institut Agama Islam Sunan Giri (INSURI) Ponorogo; wahyuhanafiputra@gmail.com \\ 2 Institut Agama Islam Sunan Giri (INSURI) Ponorogo; rizkiamalias88@gmail.com
}

\section{ARTICLE INFO}

\section{Keywords;}

Pesantren, Politics, Foreign Language

\section{A B S T R A C T}

This study aims to describe the role of foreign languages as a medium for the development of pesantren in the archipelago. The research method used is descriptive qualitative. Pesantren is one of the oldest Islamic educational institutions in Indonesia. In the history of its development, pesantren reap some barriers, until finally at the beginning of XX century pesantren began to demand by many people. The success of pesantren in managing Islamic education is partly because of the role of foreign languages (Arabic and English) taught in it. In the globalization era, foreign language is a primary requirement for students, thus making pesantren as an alternative institution in developing foreign language skills of santri, in addition, the learning of foreign languages in pesantren is more effective because of the language environment. This is one of them can make foreign language as one of the political media in order to advance the existence of pesantren. Foreign language politics in pesantren means managing foreign languages as the language of communication in various policies in pesantren. Some pesantrens in Indonesia with a background of modern pesantren and Saläf pesantren are keen to utilize foreign languages as a means of communication, resistance, and reconstruction of pesantren, such as the modern pesantren Gontor Ponorogo, Darullughah Wadda'wah Bangil Pasuruan pesantren, and Sidogiri Pasuruan pesantren. Some of these pesantren are pesantren who successfully manage foreign languages in accordance with the above functions. Thus, the paradigm of pesantren succession is not only seen from the number of santri who are proficient in Islamic Studies, but also from the extent to which santri skilled in various fields, one of which is foreign language.

\section{PENDAHULUAN}

Diskursus pergulatan demi mempertahankan eksistensi dan kemartabatan bahasa ibu dan bahasa asing di era kontemporer dirasa semakin menggeliat. Bahasa ibu sebagai akuisisi bahasa individu menjadi bahasa dasar dalam optimalisasi pengembangan bahasa asing. 


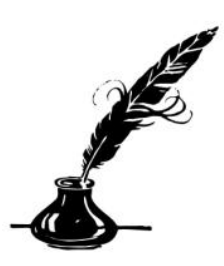

APHORISME

Journal of Arabic Language, Literature, and Education

Vol. 1, No.1 (2020)

Aphorisme@insuriponorogo.ac.id

Homepage:https://ejournal.insuriponorogo.ac.id/index.php/Aphorisme

Bahasa asing khususnya bahasa-bahasa yang telah disepakati PBB sebagai bahasa pengantar internasional menduduki posisi yang sangat strategis demi menjunjung tinggi martabat register bahasa masing-masing baik di negaranya maupun di luar negaranya. Salah satu contoh adalah bahasa Arab dan bahasa Inggris. Kedua bahasa ini menjadi bahasa pengantar internasional yang mempunyai reputasi lebih dibanding dengan bahasa Mandarin, bahasa Spanyol, bahasa Rusia, dan bahasa Prancis.

Eksistensi bahasa Arab dan bahasa Inggris di nusantara memiliki prestis dan nilai jual yang tinggi. Bahasa sebagai hasil budaya mengandung nilai-nilai para penuturnya (Sumarsono, 2017). Bahasa Arab sebagai bahasa agama Islam guna memahami literaturliteratur primer Islam, sedangkan bahasa Inggris sebagai bahasa akademis dan bahasa iptek yang sering digunakan dalam berbagai hal. Dalam konteks sejarah, hadirnya kedua bahasa ini tidak luput dari urgensi masing masing, seperti urgensi ekonomi, sosial, budaya, dan politik. Kedua bahasa ini resmi menjadi bahasa penting dalam berbagai hal di nusantara. Bahasa Arab banyak digunakan di lembaga-lembaga Islam baik negeri maupun swasta seperti madrasah, pesantren, lembaga kursus, pusat studi bahasa, dan lain-lain. Bahasa Inggris banyak digunakan pada ruang publik nasional dan internasional baik yang bersifat akademis maupun non-akademis. Manifestasi demikian telah membawa peradaban kedua bahasa tersebut melambung tinggi di era kontemporer.

Pesantren merupakan salah satu media dakwah Islam yang sudah ada lama di nusantara. Hadirnya pesantren di nusantara turut memperkaya media aktualisasi dakwah Islam. Dalam pandangan Azra, kesejarahan pesantren hingga saat ini terus melakukan akomodasi dan konsensi tertentu untuk menemukan pola yang dipandangnya cukup tepat guna menghadapi perubahan-perubahan yang kian cepat dan luas (Rafiq, 2005). Salah satu perubahan dalam tubuh pesantren di nusantara saat ini adalah dengan menguatkan pembelajaran bahasa asing (bahasa Arab dan bahasa Inggris) dengan berbagai pendekatan dan metodenya. Terminologi pesantren saat ini tidak terjebak pada sistem klasik, yakni pesantren yang berorientasi hanya pada kitab kuning, akan tetapi pesantren yang juga berorientasi pada pengembangan keterampilan santri.

Beberapa pesantren di nusantara baik yang berlatar belakang pesantren modern dan pesantren saläf saling gencar dalam memainkan bahasa asing sebagai media resistensi dan rekonstruksi pesantren, yakni pesantren modern Gontor Ponorogo, 


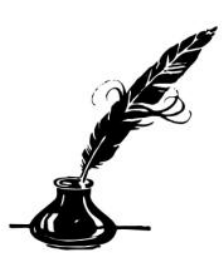

APHORISME

Journal of Arabic Language, Literature, and Education

Vol. 1, No.1(2020)

Aphorisme@insuriponorogo.ac.id

Homepage:https://ejournal.insuriponorogo.ac.id/index.php/Aphorisme

pesantren Darullughah Wadda'wah Bangil Pasuruan, dan pesantren Sidogiri Pasuruan. Pesantren-pesantren tersebut merupakan sebagian pesantren yang sukses mengelola bahasa asing sebagai bahasa komunikasi. Suksesi lembaga dalam mengelola bahasa asing menjadi daya tarik masyarakat untuk menyekolahkan putra-putrinya di pesantren tersebut. Pesantren-pesantren tersebut secara eksplisit telah mempunyai trademark "pesantren bahasa". Kebijakan-kebijakan yang berorientasi pada penuntasan pembelajaran bahasa asing telah disusun sedemikian rupa dengan sistem yang baik sehingga out-put santri dari pesantren-pesantren tersebut tidak diragukan lagi dalam menguasai bahasa Arab dan bahasa Inggris. Lantas, bagaimana kebijakan-kebijakan pengelolaan bahasa asing yang diselenggarakan oleh pesantren-pesantren tersebut, sehingga eksistensinya lebih baik daripada lembaga lain? Dan apakah kebijakankebijakan yang dilakukan pesantren demikian sangat rentan berkaitan dengan politik bahasa? Perihal ini kiranya yang harus didiskusikan secara mendalam.

\section{Politik Bahasa Asing dan Pergulatan Eksistensi Ruang Publik}

Politik dan bahasa adalah dua istilah yang sering dihubungkan. Dua istilah ini dapat kita lihat dalam dua macam hubungan. Pertama, hubungang koordinatif atau sejajar antara politik dan bahasa. Di sini politik dan bahasa berinteraksi, saling mempengaruhi, dan tarik-menarik secara setara. Keduanya saling berpengaruh dan berkontribusi karena keduanya menjadi subjek. Kedua, hubungan subordinatif atau saling membawahkan antara politik dan bahasa. Di sini, salah satu menjadi subjek dan yang lain menjadi objek. Pada satu pihak, bahasa dapat menjadi agenda kebijakan dan sasaran kajian politik, sehingga di sini politik menjadi subjek dan bahasa menjadi objek, dan pada pihak lain tuturan politik dan perilaku verbal politik dapat dilihat sebagai gejala kebahasaan dan sasaran kajian kebahasaan sehingga di sini politik menjadi objek dan bahasa menjadi subjek. Yang pertama dapat disebut dengan politik bahasa (language politics), sedangkan yang kedua dapat disebut bahasa politik (political language, linguistics of power) (Lathif, 2018). Dari kedua terma tersebut, tampaknya sangat sulit untuk menempatkan antara politik dan bahasa pada posisi masing-masing jika hanya berkutat pada sisi ontologi. Manifestasi bentuk politik dan bahasa akan diketahui berdasarkan subjek dan objeknya. Sangat tidak etis jika hanya berputar-putar dalam permasalahan ontologi baik dari terma "politik bahasa" maupun "bahasa politik. 


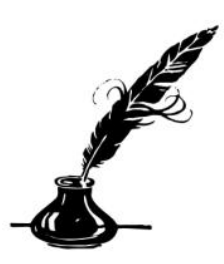

APHORISME

Journal of Arabic Language, Literature, and Education

Vol. 1, No.1(2020)

Aphorisme@insuriponorogo.ac.id

Homepage:https://ejournal.insuriponorogo.ac.id/index.php/Aphorisme

Menurut hemat peneliti, kedua terma tersebut mempunyai peran dan signifikasi yang sama meskipun dengan terminologi yang berbeda. Antara "politik" dan "bahasa" merupakan subject matter dan object matter dan sebaliknya.

Sejalan dengan itu, bisa dikatakan bahwa politik bahasa menunjuk pada kenyataan-kenyataan di mana keberadaan, keadaan, persamaan, dan perbedaan bahasa diperpolitikkan dan keberadaan, keadaan, persamaan, dan perbedaan politik dituangkan, disuarakan, dan diungkapkan dalam ungkapan atau idiom kebahasaan (Lathif, 2018). Politik bahasa bukanlah berbicara masalah kebahasaan/linguistik dari berbagai sudut pandang baik fonologi, morfologi, sintaksis, dan semantik. Akan tetapi wacana politik bahasa dirasa lebih kompleks daripada persoalan linguistik semata. Agenda politik bahasa lebih mengarah kepada pergulatan kebijakan dan pencarian eksistensi bahasa di ruang publik guna mendapatkan wilayah tertentu demi menjunjung nilai register bahasa menjadi lebih baik. Maka sangat tidak tepat jika wacana politik bahasa diserahkan kepada ahli bahasa/linguis.

Diskursus politik bahasa pada penelitian ini lebih berorientasi pada bahasa asing (bahasa Arab dan bahasa Inggris), sehingga nomenklatur yang direduksi akan menjadi lebih tegas, yakni "politik bahasa asing". Dari berbagai literatur mengenai konsep dan fungsi bahasa asing di nusantara, maka dapat direduksi bahwa pembahasan bahasa asing di nusantara sangat berkaitan dengan era globalisasi. Peranan bahasa asing semakin dirasakan penting terutama dalam berhubungan dan komunikasi antar bangsa. Di sisi lain perlu usaha untuk terus menguatkan posisi bahasa Indonesia sehingga tidak akan tergeser kedudukannya oleh bahasa asing (Herynah, 2003). Faktor globalisasi ini yang membawa berbagai lembaga pendidikan di nusantara baik yang bersifat formal, informal, dan non-formal untuk saling bersaing dan berlomba-lomba untuk mencari eksistensi di ruang publik. Salah satu lembaga pendidikan non-formal yang cukup dibilang loyal dalam pengembangan bahasa asing adalah pesantren. Di era globalisasi, bahasa asing merupakan suatu kebutuhan primer bagi pelajar, sehingga menjadikan pesantren sebagai lembaga alternatif guna mengembangkan keterampilan berbahasa asing santri dan pembelajaran bahasa asing di pesantren dirasa lebih efektif karena terbentuknya lingkungan berbahasa. Hal ini dapat menjadikan bahasa asing sebagai salah satu media politik demi memajukan eksistensi pesantren. Politik bahasa asing di 


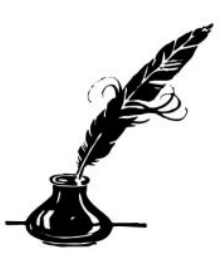

APHORISME

Journal of Arabic Language, Literature, and Education

Vol. 1, No. 1(2020)

Aphorisme@insuriponorogo.ac.id

Homepage:https://ejournal.insuriponorogo.ac.id/index.php/Aphorisme

pesantren berarti menempatkan bahasa asing sebagai media dalam memajukan pesantren.

\section{METODE}

Jenis penelitian yang digunakan dalam penelitian ini adalah penelitian lapangan (field research) yaitu suatu penelitian yang dilakukan dalam kanca kehidupan yang sebenarnya (Kartono, 1981). Penelitian ini merupakan penelitian kualitatif yang bersifat studi kasus. Kasus yang dimaksud adalah fenomena sosial terkait pembelajaran bahasa asing (bahasa Arab dan bahasa Inggris) di tiga pondok pesantren yang dijadikan lokasi penelitian. Batasan penelitian ini mengarah pada kebijakan bahasa asing yang digunakan di pondok modern Gontor Ponorogo, pesantren Darullughah Wadda'wah Bangil Pasuruan, dan pesantren Sidogiri Pasuruan. Kebijakan-kebijakan yang dimaksud ialah kebijakan penggunaan bahasa Arab dan bahasa Inggris di tiga pesantren tersebut mulai dari sistem perencanaan pembelajaran bahasa, pengelolaan pembelajaran bahasa, dan evaluasi pembelajaran bahasa. Data dalam penelitian berupa data primer dan data sekunder. Data primer berupa strategi, teknik dan metode pembelajaran bahasa Asing di tiga pesantren tersebut serta total quality management pengelolaan bahasa. Data sekunder berkaitan erat dengan pengelolaan kegiatan, waktu pelaksanaan, dan pengajar bahasa. Teknik pengumpulan data dilakukan dengan observasi, interview dan dokumentasi. Observasi dilaksanakan di lingkungan ketiga pesantren, interview dilakukan dengan mencari informasi dari responden yang masih memiliki intervensi dengan pengelola bahasa seperti bagian bahasa (Qism al-Lughah) dan pengajar bahasa. Selanjutnya teknik analisis data. Analisis data adalah proses mencari dan menyusun secara sistematis data yang diperoleh dari hasil wawancara, catatan lapangan, dan bahan-bahan lain, sehingga dapat mudah dipahami, dan temuannya dapat diinformasikan kepada orang lain. Teknik analisis data dalam penelitian ini dilakukan dengan mengidentifikasi permasalahan, memilah-milah permasalahan, mengklasifikasi, kemudian menganalisis permasalahan berdasarkan teori politik bahasa kemudian baru diambil kesimpulan wacana. 


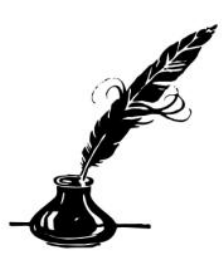

APHORISME

Journal of Arabic Language, Literature, and Education

Vol. 1, No.1(2020)

Aphorisme@insuriponorogo.ac.id

Homepage:https://ejournal.insuriponorogo.ac.id/index.php/Aphorisme

\section{PEMBAHASAN}

\section{Manifestasi Self Identity Pesantren sebagai Dampak Politik Bahasa Asing}

Bahasa sebagai self icon dalam membentuk trademark pesantren. Diskursus bahasa dalam pergulatan demi mencari eksistensi di ruang publik menjadikan pesantren berlomba-lomba dalam mengelola manajemen bahasa. Pesantren berkeinginan memiliki self identity yang cukup dikenal di masyarakat. Bahasa asing dieksploitasi sebagai media memajukan pesantren. Akuisisi bahasa asing guna memajukan pesantren di ruang publik tidak lepas begitu saja tanpa adanya sistem manajerial yang baik. Berikut adalah pesantren-pesantren yang memiliki trademark "pesantren bahasa" dan melaksanakan kebijakan pengelolaan bahasa asing dengan baik.

Pertama, Pondok Modern Darussalam Gontor. Pondok Gontor yang notabe-nya adalah pondok modern (Khaläf) telah menentukan kebijakan wajib berbahasa asing bagi seluruh santri. Bahasa dipolitisasi menjadi media primer dalam membentuk kepribadian santri yang terampil berbahasa asing. Konsep pembelajaran bahasa asing di pondok ini menggunakan paradigma strukturalis, yakni bahasa adalah sebuah ujaran, bukan sebuah tulisan (Hanafi, 2017). Salah satu tokoh stukturalisme adalah Ferdinand de Saussure. la menjelaskan aliran struktural adalah sebutan yang diberikan pada paham bahasa yang berlandaskan pada pemikiran behavioristik, jadi didasari dengan paham behavioristik hakikat bahasa itu dipandang dengan perwujudan lahiriahnya. Dalam taksonomi gramatikal disusun dari tataran terendah berupa fonem, morfem, frasa, klausa, sampai tataran tertinggi yang berupa kalimat (Chaer, 2007).

Konsep pembelajaran bahasa asing di pondok ini adalah dengan menggunakan direct method (metode langsung) yakni santri berulang-ulang untuk menghafal dan berbicara bahasa Arab dan Inggris secara sistematis baik dalam situasi formal dan nonformal. Setiap pagi selesai salat Subuh, diadakan kegiatan Tasyji' al-Lughah/ pemberian kosa kata Arab-Inggris sebagai materi berbahasa di hari tersebut. Kemudian, setelah santri menghafal kosa kata yang diberikan, santri dituntut untuk bercakap cakap menggunakan kosa kata yang telah dihafal dengan teman sejawat baik di dalam kelas (formal) dan di luar kelas (non-formal). Setelah kegiatan berlangsung dalam sehari, maka ada tahap evaluasi bahasa di malam hari yang biasa disebut dengan Mahkamah alLughah (peradilan bahasa). Lembaga Mahkamah al-Lughah diadakan guna memberi 


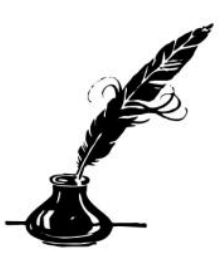

APHORISME

Journal of Arabic Language, Literature, and Education

Vol. 1, No.1 (2020)

Aphorisme@insuriponorogo.ac.id

Homepage:https://ejournal.insuriponorogo.ac.id/index.php/Aphorisme

panishme santri yang tidak menggunakan bahasa asing di hari tersebut. Secara berkala, konsep demikian akan membentuk santri lebih cepat terampil berbahasa asing, ditambah faktor habit (kebiasaan) dan lingkungan yang memadahi. Kebijakan wajib berbahasa asing dan disiplin yang ketat di pondok Gontor menjadikan lembaga memiliki prestis yang tinggi dan diminati banyak masyarakat hingga saat ini. Dalam satu kali angkatan, tak kurang dari seribu calon santri untuk mendaftarkan di lembaga ini.

Kedua, Pondok Pesantren Darullughah Wadda'wah Bangil Pasuruan. Pesantren ini memiliki reputasi yang cukup baik di kancah nasional dalam bidang bahasa Arab. Sebagaimana dijelaskan sebelumnya bahwa politik bahasa asing di pesantren berarti menempatkan bahasa asing sebagai media dalam memajukan pesantren. Beberapa staf pengajar di pesantren Darullughah Wadda'wah merupakan alumni Hadramaut, Yaman. Kebijakan pengelolaan bahasa Arab di lembaga ini adalah dengan mewajibkan santri berbahasa Arab dalam keadaan apapun. Bahasa Arab sebagai bahasa pengantar di berbagai kegiatan di pesantren ini diajarkan pada tahun pertama santri masuk, kemudian dipelajari secara mendalam di tahun berikutnya berdasarkan kurikulum yang berlaku. Bahasa Arab di pesantren ini digunakan dalam susana formal seperti ketika pelajaran di kelas, dan suasana non-formal seperti kegiatan ekstrakurikuler, Muhaḍarah (pidato), Baḥs al-Masāil (musyawarah), dan Muḥādasiah al-Yaumiyyah (percakapan sehari-hari). Misi lembaga dalam mengelola pembelajaran bahasa Arab di pesantren ini adalah agar santri terampil berbahasa Arab baik ketika masih menjadi santri maupun sudah lulus. Bahasa Arab sebagai bahasa mendalami ilmu-ilmu agama Islam menjadikan motivasi tersendiri kepada lembaga untuk terus mengevaluasi pengelolaan pembelajaran bahasa Arab. Paradigma yang digunakan dalam pembelajaran bahasa Arab di pesantren Darulllughah Wadda'wah adalah paradigmas strukturalis, sehingga pendekatan yang digunakan adalah pendekatan keterampilan (al-Madkhal al-Mahārī) dan metode langsung (al-Țarīqah al-Mubāsyarah).

Ketiga, Pesantren Sidogiri Pasuruan. Merupakan pesantren yang cukup tua di nusantara dan memiliki reputasi nasional yang baik. Pesantren ini dikenal karena memiliki lembaga ekonomi yang cukup mapan. Kebijakan pengelolaan pembelajaran bahasa di pesantren ini adalah dengan memberikan kelas khusus (takhașsus) bagi santri yang mempelajari bahasa Arab dan Inggris. Santri yang memasuki kelas khusus akan 


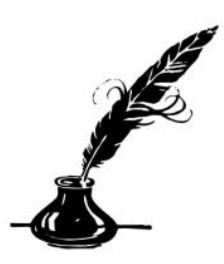

APHORISME

Journal of Arabic Language, Literature, and Education

Vol. 1, No.1 (2020)

Aphorisme@insuriponorogo.ac.id

Homepage:https://ejournal.insuriponorogo.ac.id/index.php/Aphorisme

digembleng secara intensif. Pesantren ini memfasilitasi asrama bahasa bagi santri yang memilih jalur takhașs us bahasa. Aspek keterampilan berbahasa Arab yang disentuh mulai dari keterampilam mendengar (Mahārah al-Istimā'), keterampilan berbicara (Mahārah al-Kalām) dengan aktualisasi pembelajaran intensif seperti Muhādasiah (percakapan), Muhậarah (pidato), Tațī̄q al-Lughah (aktualisasi bahasa), dan Mujādalah (debat). Selanjutnya untuk aspek keterampian berbicara (Mahārah al-Qirā'ah) dan keterampilan menulis (Mahārah al-Kitābah) adalah dengan penguatan Gramatikal Arab secara intens seperti kegiatan Bahs al-Kutub al-Turās wa al-Mu'așirah (bedah kitab klasikkontemporer). Dari keempat aspek keterampilan berbahasa tersebut disampaikan dengan teknik arabic speaking secara totalitas. Dari sini lah keterampilan berbahasa santri mulai terasah dan mulai tampak hasilnya secara berkala, sehingga menghasilkan santri yang terampil dalam sisi bahasa Arab ujaran dan tulisan.

\section{Eskalasi Politik Bahasa di Pesantren dan Rekognisi Lembaga}

Kebijakan pengelolaan bahasa asing di tiga pesantren tersebut, baik dari Pondok Modern Gontor, Pesantren Darullughah Wadda'wah Bangil Pasuruan, dan Pesantren Sidogiri Pasuruan telah membuktikan bahwa bahasa asing yang dikelola di pesantren mampu menghegemoni pesantren menjadi lebih survive dan memenangkan percaturan politik pendidikan di nusantara. Sebagai imbasnya, pesantren-pesantren tersebut menjadi pesantren pilihan masyarakat dalam mengembangkan Islamic Studies dan bahasa asing. Pesantren-pesantren tersebut juga memberi bukti bahwa kesuksesan seseorang berbahasa asing tidak harus memasuki lembaga pendidikan formal, akan tetapi juga bisa dengan memasuki lembaga pendidikan Islam non-formal.

Konsep modernisasi pesantren dimulai dari pembelajaran kitab klasik atau kitab kuning seperti halnya di singgung di PP. Darullughah Wadda'wah Bangil Pasuruan di atas. Pembelajaran kitab klasik (Kitab al-Turaś) merupakan embrio lahirnya pesantren di nusantara. Tidak disebut pesantren jika tidak mengajarkan kitab kuning di dalamnya. Seiring dengan pergeseran dan perkembangan kurikulum, kitab kuning turut menyesuaikan keadaan kebutuhan pendidikan yang ada. Azyumardi Azra (2011) mendefinisikan kitab kuning sebagai kitab keagamaan yang berbahasa Arab, Melayu atau Jawa dan atau bahasa-bahasa lokal lain di seantero Indonesia dengan menggunakan aksara Arab yang ditulis oleh ulama Timur Tengah dan ditulis pula oleh ulama asli 


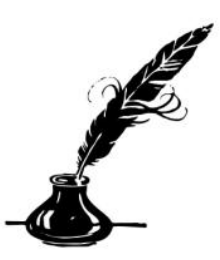

APHORISME

Journal of Arabic Language, Literature, and Education

Vol. 1, No.1(2020)

Aphorisme@insuriponorogo.ac.id

Homepage:https://ejournal.insuriponorogo.ac.id/index.php/Aphorisme

Indonesia. Mengutip pendapat tersebut, kitab kuning merupakan aksara Arab yang memiliki konten Islamic Studies seperti fikih, tasawuf, kalam, tafsir, dan cakupan Islamic Studies yang lain.

Reorientasi kitab kuning sebagai kitab berbahasa Arab turut menghegemoni kekuatan politik bahasa Arab di nusantara. Rumpun bahasa Semith ini memiliki ribuan penutur di nusantara semenjak kitab kuning wajib diajarkan di pesantren. Kekuatannya terdapat di dalam kitab kuning itu sendiri. Setiap Kiai dan ustaz yang mengajar kitab kuning secara periodik, maka akan dimengerti santri secara berkala. Penguasaan bahasa Arab yang mengarah kepada Mafhūm al-Maqrū' ini lebih mudah jika diiringi dengan penguasaan ilmu alat tata bahasa Arab.

Eksistensi kitab kuning yang samula diajarkan di pesantren tradisional (salaf) kini mengembang diajarkan di pesantren modern (khaläf). Sebagai bentuk penguasaan bahasa Asing terutama bahasa Arab, tema-tema kitab kuning yang digunakan di pesantren modern turut menyesuaikan aspek penguasaan bahasa Arab percakapan (Mafhūm al-Kalām) misalnya bahasa Arab sehari-hari. Ilmu tata bahasa Arab yang digunakan juga menyesuaikan orientasi Mafhūm al-Kalām. Dengan dimikian, kini sudah tidak ada lagi Quo Vadis dan dikotomi peguasaan bahasa Asing di pesantren tradisional dan pesantren modern. Kedua lembaga ini memiliki rekognisi dan kekuatan besar di dalam kurikulumnya terutama dalam penguasaan bahasa Arab. Eksistensi bahasa Inggris sebagai bahasa pokok yang diajarkan di pesantren modern tidak lepas dari keberhasilan pengajaran bahasa Arab yang lebih dulu. Rekognisi pesantren sebagai lembaga pengembangan bahasa kini masyhur di masyarakat umum. Saat ini pesantren tidak hanya dikenal sebagai lembaga memperdalam ilmu agama. Makna demikian kian meluas. Saat ini pesantren telah menemukan jati dirinya sebagai lembaga yang unggul dan memiliki prestis baik.

\section{PENUTUP}

\section{Kesimpulan}

Bahasa asing di era kontemporer mempunyai signifikasi yang begitu penting. Bercermin dengan hal tersebut, kini lembaga-lembaga pendidikan terus bersaing satu sama lain guna mencari eksistensi. Salah satu lembaga pendidikan Islam yang begitu intens dalam 


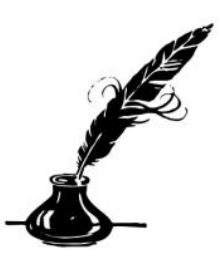

APHORISME

Journal of Arabic Language, Literature, and Education

Vol. 1, No. 1(2020)

Aphorisme@insuriponorogo.ac.id

Homepage:https://ejournal.insuriponorogo.ac.id/index.php/Aphorisme

pembelajaran bahasa asing adalah pesantren. Pesantren sebagai salah satu media dakwah Islam klasik yang menuai pesat di abad XX turut andil dalam pengembangan pendidikan terutama pendidikan Islam. Suksesi pesantren tidak lepas dari peran pengelolaan bahasa asing, sehingga tampak dari beberapa pesantren di nusantara menjadikan bahasa asing sebagai media politik pendidikan. Beberapa pesantren di nusantara yang berlatarbelakang pesantren modern dan pesantren tradisional saling gencar dalam memainkan bahasa asing sebagai media resistensi dan rekonstruksi pesantren. Misalnya pesantren modern Gontor Ponorogo, Pesantren Darullughah wadda'wah Bangil Pasuruan, dan Pesantren Sidogiri Pasuruan. Pesantren-pesantren tersebut memiliki jumlah santri yang cukup besar dibanding dengan pesantren yang lain di nusantara. Minatnya masyarakat dalam memilih pesantren-pesantren tersebut salah satunya adalah karena faktor pengelolaan pembelajaran bahasa asing yang baik. Dengan demikian, paradigma suksesi pesantren tidak hanya ditinjau dari banyaknya santri yang mahir dalam bidang Islamic Studies, akan tetapi juga ditinjau dari sejauh mana santri terampil dalam berbagai bidang yang salah satunya adalah berbahasa asing.

\section{Saran}

Sudah saatnya lembaga pendidikan di nusantara baik yang berafiliasi pendidikan umum maupun pendidikan agama untuk memposisikan bahasa asing sebagai media dalam memajukan lembaga. Karena, mau tidak mau saat ini kita memasuki wilayah globalisasi yang menuntut generasi muda untuk terampil berbahasa asing. Dengan demikian, alangkah baiknya jika lembaga pendidikan apapun di nusantara turut andil dalam memerankan bahasa asing sebagai bahasa yang wajib dipelajari guna membentuk generasi muda yang terampil berbahasa asing sehingga siap dalam menghadapi globalisasi. Meskipun demikian, bukan berarti harus menafikan peran bahasa daerah. Bahasa daerah sebagai produk budaya kearifan lokal patut untuk dipertahankan sebagai bentuk melestarikan budaya lokal. Seperti pepatah yang mengatakan "kuasai bahasa asing, gunakan bahasa nasional, dan lestarikan bahasa daerah". 


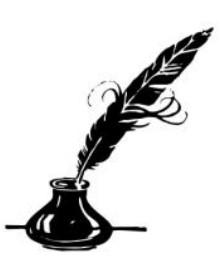

APHORISME

Journal of Arabic Language, Literature, and Education

Vol. 1, No.1(2O2O)

Aphorisme@insuriponorogo.ac.id

Homepage:https://ejournal.insuriponorogo.ac.id/index.php/Aphorisme

\section{BIBLIOGRAFI}

Azra, Azyumardi. 2011. Pendidikan Islam; Tradisi dan Modernisasi di Tengah Tantangan Milenium III. Yogyakarta: Media Group.

Chaer, Abdul. 2007. Linguistik Umum. Jakarta: Rineke Cipta.

Dwi Purnomo, Maslathif. 2018. Politik Bahasa di Tengah Kemajemukan Masyarakat, https://pakarlinguistik.wordpress.com/2010/03/10/politik-bahasaditengah-kemajemukan-budaya-bangsa/.

Hanafi, Wahyu. 2017. Diglosia Bahasa Arab Pesantren dan Upaya Pemertahanan Bahasa Daerah. Jurnal Qolamuna. Vol. 10 No. 2.

Heryanah. 2003. Politik Bahasa. Jurnal Masyarakat dan Budaya, Vol. 5 No. 1.

Kartono, Kartini. 1981. Pengantar Metodologi Riset Sosial. Jakarta: Gramedia

Pustaka

Rofiq A, dkk. 2005. Pemberdayaan Pesantren: Menuju Kemandirian dan Profesionalisme Santri dengan Metode Daurah Kebudayaan. Yogyakarta: LKiS.

Sumarsono. 2017. Sosiolinguistik, Yogyakarta: Pustaka Pelajar. 